\title{
Assessment of Soil Carbon Stock Status of Sekelemariam Dry Evergreen Montane Forest Along Altitudinal Gradient: Implication for Climate Change Mitigation
}

\author{
Yitayal Tebeje Workie \\ College of Agriculture and Natural Resources, Debre Markos University, Debre Markos, Ethiopia \\ Email address: \\ yitayal_tebeje@dmu.edu.et \\ To cite this article: \\ Yitayal Tebeje Workie. Assessment of Soil Carbon Stock Status of Sekelemariam Dry Evergreen Montane Forest Along Altitudinal Gradient: \\ Implication for Climate Change Mitigation. International Journal of Sustainable and Green Energy. Vol. 10, No. 1, 2021, pp. 1-6. \\ doi: $10.11648 /$ j.ijrse.20211001.11
}

Received: August 11, 2020; Accepted: September 7, 2020; Published: January 22, 2021

\begin{abstract}
This study was conducted in Sekelemariam Dry Evergreen Montane Forest which is situated within $37^{\circ} 27^{\prime}$ and $37^{\circ} 30^{\prime}$ east, and $10^{\circ} 34^{\prime}$ and $10^{\circ} 36^{\prime}$ north, near Dembecha Town in west Gojam Zone, North Western Ethiopia. It is characterized by steeply sloped areas with huge Rocky Mountains extended throughout the middle parts of the forest. The aim of this study was to estimate the soil carbon stock potential of the forest. A systematic transect sampling technique was adopted in this study and following these transects plots of $1 \mathrm{mx} 1 \mathrm{~m}\left(1 \mathrm{~m}^{2}\right)$ data was taken from the field. The carbon stock density of soil organic carbon was calculated from the volume and bulk density of the soil as $\mathrm{V}=\mathrm{h} \times \pi \mathrm{r}^{2}$. The data analysis was conducted using Microsoft excel sheet used as platform in carbon calculations, and SPSS software version 20 to determine the impact of altitude gradient and slope factors on soil carbon stock potential and to compare the relationship between dependent and independent variables. The carbon stock of the SOC showed increasing trend with increasing elevation. In contrast to the elevation, the forest soil carbon stock decreases as increasing slope gradient. Soil laboratory analysis was conducted in Holeta Agricultural Research center to determine the soil organic carbon density and was estimated to be101.56 $\pm 3.66 \mathrm{t} \mathrm{C}$ ha-1. All in all, this study gives estimation of the soil carbon stock in Sekelemariam State Forest.
\end{abstract}

Keywords: Soil Carbon Stock, Soil Organic Carbon, Slope Gradient, Altitudinal Gradient

\section{Introduction}

\subsection{Background}

The issue of global climate change has become a central issue and concern of the world by all people at local, regional, national and international levels. Global warming and climate change arising due to the greenhouse effect / Greenhouse Gas (GHG) emissions resulting from the effects of development activities in various business sectors, including land use, changes in the function and forest allocation, forest and land fires, a decrease in quality of forests from uncontrolled utilization, as well as the burning of fossil energy [17].

Anthropogenic emission of carbon dioxide leads to global warming and climate change affecting the biodiversity and destabilizing food and livelihood security. Rise in atmospheric $\mathrm{CO}_{2}$ is because of large scale burning of oil, coal and natural gas, which are the energy sources for modern industrial economies and due to deforestation [13]. Forests are one of the major pools of carbon since plants fix atmospheric carbon in the tissues; thereby transform carbon from atmosphere to the biological systems.

Forests ecosystems sequester and store more carbon than any other terrestrial ecosystem and hence are an important natural 'brake' on climate change. More than $40 \%$ of the total organic $\mathrm{C}$ in terrestrial ecosystems is stored in forest soil and thus management practices need to address the soil carbon pool. Converting natural forests to agricultural land results in the mineralization of soil organic $\mathrm{C}$ (SOC), thus reducing SOC stocks and increasing atmospheric $\mathrm{CO} 2$ concentrations [2]. The decreases in SOC following a landuse change are difficult to predict due to variations in the factors that drive SOC mineralization, e.g., forest type, 
climate, and soil properties [10]. Drake et al., [5] reported that total quantity of $\mathrm{C}$ entering the soil via litter fall and all belowground $\mathrm{C}$ inputs increased $17 \%$ from c. $1.50 \mathrm{~kg} \mathrm{C} \mathrm{m}$ year1 under ambient $\mathrm{CO}_{2}$ to c. $1.75 \mathrm{~kg} \mathrm{C} \mathrm{m}{ }^{2}$ year-1 under elevated $\mathrm{CO}_{2}$. However, these increases in $\mathrm{C}$ entering the soil under elevated $\mathrm{CO}_{2}$ was matched by increased $\mathrm{C}$ loss attributable to significant increases in fine and coarse root respiratory fluxes (i.e., autotrophic respiration) and a significant increase in heterotrophic respiration [5].

When forests are destroyed or degraded, their stored carbon is released into the atmosphere as carbon dioxide $\left(\mathrm{CO}_{2}\right)$ [13]. These alterations cascade through the ecosystem, resulting in increased temperature altered rainfall patterns and degraded soil profiles. Carbon accumulation potential in forests is large and the period of carbon retention is long [13], so, they offer the possibility of sequestering significant amounts of additional carbon in relatively short period and keep it for many years.

According to FAO [6], the forest resources of Ethiopia store an estimated 2.76 billion tons of carbon, playing a significant role in the global carbon balance. The largest store of carbon in the country is found in the woodlands (46\%) and the shrub lands (34\%), while the high forests store about $16 \%$. REDD negotiations and other carbon related policies and projects should not neglect the woodland and shrub land resources. Likewise, trees outside forests are often overlooked.

\subsection{Statement of the Problem}

Long-term monitoring has shown that the amount of $\mathrm{CO}_{2}$ in the atmosphere is increasing due to human activities. This is causing the earth to warm and the oceans to become more acidic. Unless the amount of $\mathrm{CO}_{2}$ and other greenhouse gases emitting to the atmosphere can be reduced dramatically, scientists predict that the temperature of the earth will continue to rise, and this rise in temperature will cause the climate to change, sea levels to rise, and ocean and land environments to be adversely affected.

Forests ecosystems sequester and store more carbon than any other terrestrial ecosystem and hence are an important natural 'brake' on climate change. More than $40 \%$ of the total organic $\mathrm{C}$ in terrestrial ecosystems is stored in forest soil and thus management practices need to address the soil carbon pool.

Although forests have a great potential for carbon storage, they are often not given due attention by researchers and development organizations and the responsible government, concerning about carbon and climate change at large [18].

Soils are fundamental to our life and must be recognized and valued for their importance in global feedbacks to climate change and in particular their large potential to mitigate climate change.

The effects of changes in soil management, such as increased soil disturbance and aeration, the addition of fertilizers, and changes in residue amount and quality, have often been cited as primary factors in the changes of soil organic matter from native levels [8].

Although there are case studies on soil carbon pools for selected parts of Ethiopia estimate on national soil carbon pools is missing. National soil database carbon pools estimate, which currently does not exist in Ethiopia [7]. According to Adugna et al., [1], information on carbon stocks of forest is limited in Ethiopia. The carbon sequestration potential of Sekelemariam Forest has therefore not been assessed yet.

\subsection{Objectives}

This study was conducted to achieve the following objectives:

1) To investigate the altitudinal variations in soil stock potential of the study area

2) To analyze the role of forest in forest soil carbon sequestration

3) To investigate the soil carbon stock potential along slope gradients

4) To provide baseline information for future conservation and management of the forest and the soil

\section{Materials and Methods}

\subsection{Geographical Location}

This study was conducted in Dembecha district, Amhara National Regional State, north wstern parts of Ethiopia which is situated within $37^{\circ} 27^{\prime}$ and $37^{\circ} 30^{\prime}$ east, and $10^{\circ} 34^{\prime}$ and $10^{\circ} 36^{\prime}$ north, near Dembecha Town in west Gojam Zone. The study covers 543 hectares. The natural plants of the forest has been deforested and converted to plantations through rehabilitation programs. The forest has an altitudinal gradient ranging from $2249 \mathrm{~m}$ to $2470 \mathrm{~m}$ above sea level. This forest contains diverse fauna and flora species which are currently found in danger.

\subsection{Topography and Climate}

The Forest is characterized by dissected plateaus bordered by cultivated lands in all directions. The natural forest vegetation is concentrated at the middle and lowest altitudes, while the upper altitude which is the top plateau area of the forest is mainly occupied by plantations. It is characterized by steeply sloped areas with huge Rocky Mountains extended throughout the middle parts of the forest. The forest also consists of small and seasonal rivers drained from the top of the forest to the lower settlement areas.

The mean annual rainfall of the study area is $1502.01 \mathrm{~mm}$ ranging from $1283.10 \mathrm{~mm}$ minimum in 2009 to maximum of $1639.4 \mathrm{~mm}$ in 2010 with the rains mainly falling from the end of May to September. The mean temperature of the surrounding area is about $18.74^{\circ} \mathrm{C}$ with a maximum of $27.04^{\circ} \mathrm{C}$ and minimum of $9.65^{\circ} \mathrm{C}$ and is generally characterized by moderate climate. 


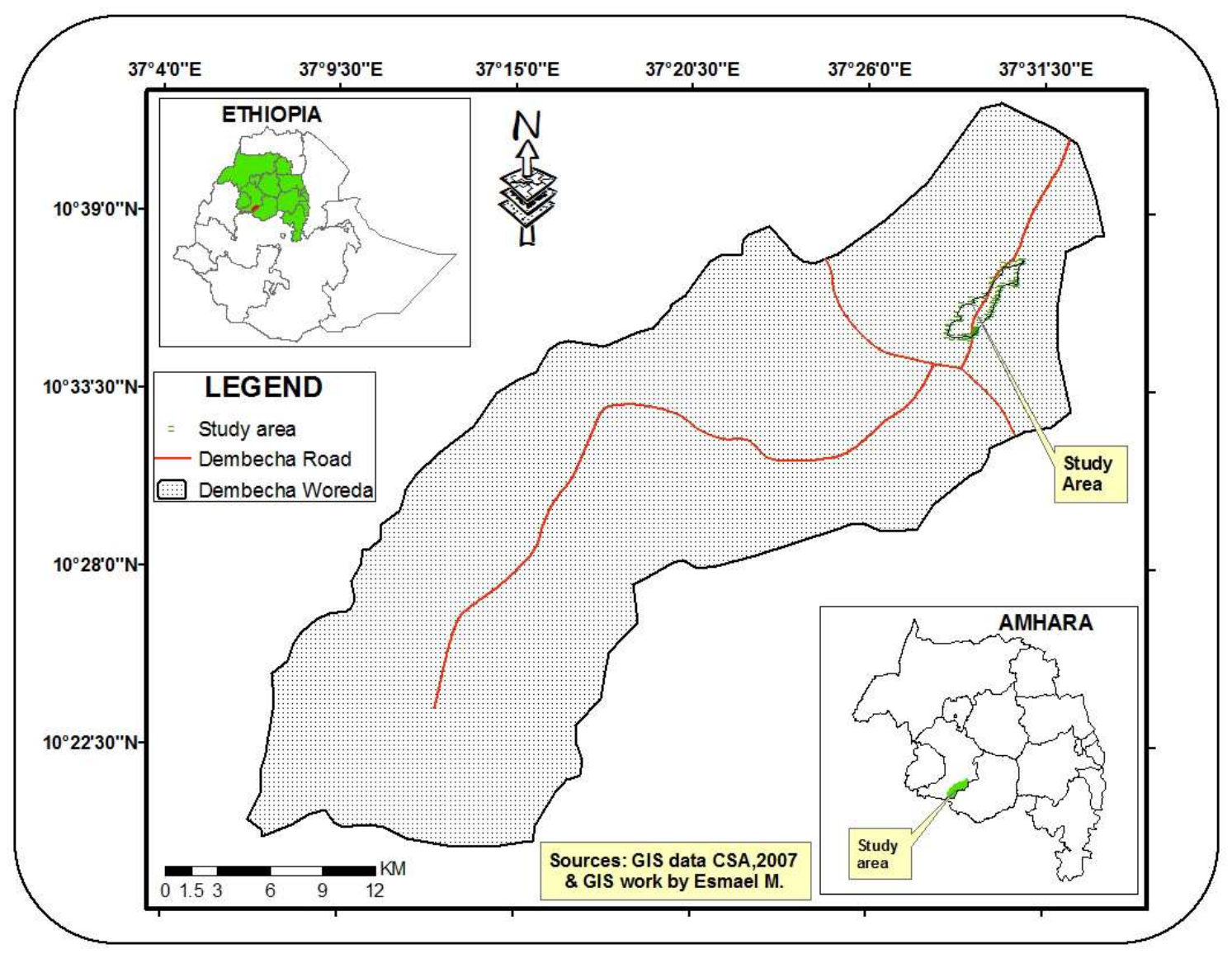

Figure 1. Map of Ethiopia showing Regional States and the Study Area.

\subsection{Methodology}

\subsubsection{Delineation of the Study Area}

Delineation of study boundary using GPS tracking and stratification of the study area depending on environmental gradient was the first step in measuring and estimating carbon stocks in the above mentioned carbon pools.

\subsubsection{Sampling Techniques}

Once the study area has been delineated, the study site was divided into different strata of homogeneous units as possible based on the altitudinal gradients of the forest as bottom, middle and top. Thus, altitude was taken as the criteria for stratification, since the study area has an altitudinal variation which is easily possible to determine the relationship between environmental gradient and forest carbon stock of the study area.

Sampling sites from the forest were arranged by the line transects from the bottom area of the forest to top directions covering the whole range of altitudes. A plot of $10 \mathrm{~m} \times 20 \mathrm{~m}$ $\left(200 \mathrm{~m}^{2}\right)$ was applied along the transect lines at approximately $200 \mathrm{~m}$ to $250 \mathrm{~m}$ distance between each plot.

\subsubsection{Shape of Sample Plots}

According to Brown [4], even though both rectangular and circular plots are applicable in most of the forest carbon measurements, rectangular plots are more advantageous and recommended for this study.

\subsection{Field Measurements}

Vegetation Survey: Diameter and Height Measurement

The Soil sample was collected from four sub-quadrats of 1 $\mathrm{m} \times 1 \mathrm{~m}\left(\mathrm{~m}^{2}\right)$ of the large plot $10 \mathrm{mx} 20 \mathrm{~m}\left(200 \mathrm{~m}^{2}\right)$ at each corner the quadrat. A total of 500 gram mixed sample was taken from each a quadrat. Altitude was measured for each sample plot using GPS 60 with a precision level of $\pm 7 / 8$ and for each sample plot the latitude and longitude coordinates were taken in UTM coordinates. Similarly, slope for each plot was recorded using a clinometer.

\subsection{Determination of Soil Organic Carbon}

Soil is the largest carbon reservoir pool of terrestrial ecosystem and plays a key role in the global carbon budget and greenhouse effect [12].

Soil organic carbon was determined through samples collected from the default depth $30 \mathrm{~cm}$ prescribed by the IPCC (2006) [9]. Based on findings that support as much as $60 \%$ of stored carbon has been found at this depth [11] and that at lower depths, stored carbon tends more stable since the soil is less altered by mechanization practices or by changes in forest cover.

The activities of carbon measurement during the field data collection was soil organic carbon measurements.

In the laboratory, soil samples were dried at $105^{\circ} \mathrm{C}$ for 24 
hours to remove the soil moisture and to determine the percentage of organic carbon as well as the bulk density [16].

To obtain an accurate inventory of organic carbon, soil depth, soil bulk density (calculated from the oven-dry weight of soil from a known volume of sampled material), and concentrations of organic carbon within the sample [10]. The soil samples for soil carbon determination were collected at the plot prepared $1 \mathrm{mx} 1 \mathrm{~m}\left(1 \mathrm{~m}^{2}\right)$ a pit of up to $30 \mathrm{~cm}$ in depth was dug to best represent forest types in terms of slope, vegetation, density, and cover.

The soil samples collected from the plot were labeled and tagged brought to the laboratory, placing them in sample plastic bags. The samples were taken to Holeta Agricultural Research Center. Then, the bulk density and amounts of soil organic carbon were determined.

The carbon stock density of soil organic carbon can be calculated as recommended by Pearson et al., [14]. from the volume and bulk density of the soil as

$$
\mathrm{V}=\mathrm{h} \times \pi \mathrm{r}^{2}
$$

More over the bulk density of a soil sample can be calculated as follows:

$$
\mathrm{BD}=\frac{\text { Wav,dry }}{\mathrm{V}}
$$

where BD is bulk density of the soil sample per, $\mathrm{W}_{\mathrm{av}}$, dry is average air dry weight of soil sample per the quadrant, $\mathrm{V}$ is volume of the soil sample in the core sampler auger in $\mathrm{cm}^{3}$ [14].

$$
\mathrm{SOC}=\mathrm{BD} * \mathrm{~d} * \% \mathrm{C}
$$

Where $\mathrm{SOC}=$ soil organic carbon stock per unit area $\left(\mathrm{t} \mathrm{ha}^{-1}\right)$, $\mathrm{BD}=$ soil bulk density $\left(\mathrm{g} \mathrm{cm}^{-3}\right)$,

$\mathrm{D}=$ the total depth at which the sample was taken $(30 \mathrm{~cm})$, and $\% \mathrm{C}=$ Carbon concentration $(\%)$.

\subsection{Data Analysis}

The data analysis was done using Microsoft excel sheet and SPSS version 16 software. Soil data collected from field and data determined from laboratory analysis such as dry weight of soil, bulk density of soil and soil carbon contents were analyzed using Microsoft excel as a platform in the biomass and carbon calculations as well as Statistical Product for Service Solutions (SPSS) software version 16 to determine the relationship between dependant and independent variables and other statistical parameters. One simple T-Test was used to compute the mean values and mean standard errors of the variables.

\section{Results and Discussion}

\subsection{Soil Organic Carbon and Bulk Density Determination}

The potential long term average soil carbon storage was calculated separately for each of the different plots along altitudinal variations. Thus, in this study, 66 sample plots were recorded (for this particular study of carbon stock

\begin{tabular}{|c|c|c|c|c|c|c|c|}
\hline Field No & Depth (cm) & Volume (ml) & wt of dry sample (g) & Bulk density $\left(\mathrm{g} / \mathrm{cm}^{3}\right)$ & $\% \mathrm{OC}$ & SOC & $\mathrm{SOCO}_{2}$ \\
\hline 1 & 30 & $70 \mathrm{ml}$ & 73.8 & 1.1 & 2.84 & 93.720 & 343.95 \\
\hline 2 & $>>$ & $>>$ & 67.7 & 0.97 & 3.74 & 108.834 & 399.42 \\
\hline 3 & $>$ & $>>$ & 68.8 & 0.98 & 3.51 & 103.194 & 378.72 \\
\hline 4 & $>>$ & $>>$ & 65.9 & 0.94 & 2.46 & 69.372 & 254.60 \\
\hline 5 & $>>$ & $>>$ & 73.5 & 1.1 & 2.88 & 95.040 & 348.80 \\
\hline 6 & $>$ & $>>$ & 64.3 & 0.92 & 2.84 & 78.384 & 287.67 \\
\hline 7 & $>>$ & $>>$ & 67.5 & 0.96 & 2.1 & 60.480 & 221.96 \\
\hline 9 & $>>$ & $>>$ & 69.1 & 0.99 & 2.03 & 60.291 & 221.27 \\
\hline 10 & $>>$ & $>>$ & 70.8 & 1.01 & 2.22 & 67.266 & 246.87 \\
\hline 11 & $>$ & $>$ & 69.8 & 1 & 2.53 & 75.900 & 278.55 \\
\hline 12 & $>>$ & $>>$ & 69.2 & 0.99 & 1.99 & 59.103 & 216.91 \\
\hline 13 & $>>$ & $>>$ & 73.1 & 1.04 & 2.42 & 75.504 & 277.10 \\
\hline 14 & $>>$ & $>>$ & 76 & 1.1 & 2.77 & 91.410 & 335.47 \\
\hline 15 & $>>$ & $>>$ & 69.8 & 1 & 2.65 & 79.500 & 291.77 \\
\hline 18 & $>$ & $>>$ & 69.1 & 0.99 & 2.84 & 84.348 & 309.56 \\
\hline 19 & $>$ & $>$ & 72.6 & 1.04 & 2.53 & 78.936 & 289.70 \\
\hline 20 & $>>$ & $>>$ & 69.2 & 1 & 2.3 & 69.000 & 250.70 \\
\hline 21 & $>>$ & $>>$ & 73.3 & 1.05 & 3.59 & 113.085 & 415.02 \\
\hline 22 & $>>$ & $>>$ & 64.6 & 0.92 & 2.88 & 79.488 & 291.72 \\
\hline 23 & $>>$ & $>>$ & 69.1 & 0.99 & 2.53 & 75.141 & 275 . \\
\hline 24 & $>$ & $>$ & 74 & 1.1 & 1.83 & 60.390 & 221.63 \\
\hline 25 & $>>$ & $>>$ & 68.1 & 0.97 & 3.43 & 99.813 & 366.31 \\
\hline 26 & $\gg$ & $>>$ & 78.9 & 1.13 & 2.07 & 70.173 & 257.53 \\
\hline 27 & $>>$ & $>>$ & 72.8 & 1.1 & 3.43 & 113.190 & 415.41 \\
\hline 28 & $>$ & $>$ & 68.7 & 1 & 2.07 & 62.100 & 227.91 \\
\hline 29 & $>>$ & $>>$ & 67.1 & 0.96 & 3.43 & 98.784 & 362.54 \\
\hline 30 & $>$ & $>>$ & 74 & 1 & 3.74 & 112.200 & 411.77 \\
\hline
\end{tabular}
estimation) from the study site, Sekelemariam State Forest.

Table 1. Laboratory analysis for soil organic carbon and bulk density determination. 


\begin{tabular}{|c|c|c|c|c|c|c|c|}
\hline Field No & Depth (cm) & Volume (ml) & wt of dry sample (g) & Bulk density $\left(\mathrm{g} / \mathrm{cm}^{3}\right)$ & $\% \mathrm{OC}$ & SOC & $\mathrm{SOCO}_{2}$ \\
\hline 31 & $>>$ & $>$ & 73.5 & 1.1 & 2.73 & 90.090 & 330.63 \\
\hline 32 & $>$ & $>$ & 73.2 & 1.1 & 2.73 & 90.090 & 330.63 \\
\hline 33 & $>$ & $>$ & 73.0 & 1.1 & 2.81 & 92.730 & 340.32 \\
\hline 34 & $>$ & $>$ & 75.9 & 1.1 & 3.82 & 126.060 & 462.64 \\
\hline 35 & $>>$ & $>$ & 73.8 & 1.1 & 3.12 & 102.960 & 377.86 \\
\hline 36 & $>$ & $>$ & 74.7 & 1.1 & 4.83 & 159.390 & 584.96 \\
\hline 37 & $>$ & $>$ & 70.7 & 0.99 & 4.44 & 131.868 & 483.96 \\
\hline 38 & $>$ & $>$ & 70.5 & 0.99 & 4.21 & 125.037 & 458.89 \\
\hline 39 & $>$ & $\gg$ & 70.8 & 1 & 2.57 & 77.100 & 282.96 \\
\hline 40 & $>$ & $>$ & 71.5 & 1 & 3.27 & 98.100 & 360.03 \\
\hline 41 & $>$ & $>$ & 69.0 & 1 & 2.42 & 72.600 & 266.44 \\
\hline 42 & $\gg$ & $\gg$ & 74.0 & 1.1 & 4.44 & 146.520 & 537.73 \\
\hline 43 & $>>$ & $>>$ & 76.1 & 1.1 & 4.44 & 146.520 & 537.73 \\
\hline 44 & $\gg$ & $>$ & 72.3 & 1.1 & 2.65 & 87.450 & 320.94 \\
\hline 45 & $>>$ & $>$ & 69.7 & 1 & 3.59 & 107.700 & 395.26 \\
\hline 46 & $>$ & $>>$ & 69.5 & 1 & 4.99 & 149.700 & 549.40 \\
\hline 47 & $>$ & $>$ & 70.5 & 1 & 2.81 & 84.300 & 309.38 \\
\hline 48 & $>>$ & $>$ & 70.9 & 1 & 3.43 & 102.900 & 377.64 \\
\hline 49 & $>$ & $>>$ & 68.2 & 1.1 & 3.59 & 118.470 & 434.78 \\
\hline 50 & $>$ & $>>$ & 62.8 & 0.95 & 3.59 & 102.315 & 375.50 \\
\hline 51 & $>$ & $>$ & 65.5 & 0.98 & 4.05 & 119.070 & 436.99 \\
\hline 52 & $>>$ & $>>$ & 72.9 & 1 & 3.74 & 112.200 & 411.77 \\
\hline 53 & $>$ & $>>$ & 83.7 & 0.97 & 5.69 & 165.579 & 607.67 \\
\hline 54 & $>$ & $>$ & 84.5 & 0.97 & 3.51 & 102.141 & 374.86 \\
\hline 55 & $>$ & $>>$ & 77.8 & 1 & 4.05 & 121.500 & 445.91 \\
\hline 56 & $>>$ & $>>$ & 88.2 & 1 & 4.91 & 147.300 & 540.59 \\
\hline 57 & $>>$ & $>$ & 81.7 & 1 & 4.05 & 121.500 & 445.91 \\
\hline 58 & $>$ & $>>$ & 74.3 & 0.96 & 4.6 & 132.480 & 486.20 \\
\hline 59 & $>>$ & $>>$ & 81.6 & 1 & 5.92 & 177.600 & 651.79 \\
\hline 60 & $>>$ & $>$ & 83.4 & 1.1 & 5.53 & 182.490 & 669.74 \\
\hline 61 & $>>$ & $>>$ & 82.4 & 0.98 & 3.59 & 105.546 & 387.35 \\
\hline 62 & $>>$ & $>$ & 86.1 & 1 & 3.66 & 109.800 & 402.97 \\
\hline 63 & $>>$ & $>>$ & 83.5 & 0.98 & 3.2 & 94.080 & 345.27 \\
\hline 64 & $>>$ & $>>$ & 71.8 & 1 & 4.6 & 138.000 & 506.46 \\
\hline 65 & $>>$ & $>>$ & 77.7 & 1 & 2.96 & 88.800 & 325.90 \\
\hline 66 & $\gg$ & $\gg$ & 86.3 & 1 & 3.66 & 109.800 & 402.97 \\
\hline
\end{tabular}

According to the Lab analysis shown above in Table 1, the minimum and maximum bulk density identified in soil lab analysis was 0.92 and 1.13 , respectively. The study site was found to measure an overall mean value of $101.00 \pm 3.66$ tones $\mathrm{ha}^{-1}$ at $(95 \%)$ CI. A total of 6703.08 tones SOC were estimated from the total study site. Soil $\mathrm{CO}_{2}$ concentration also had similar pattern with soil organic carbon concentration with a mean value of $372.73 \pm 13.45 t h a^{-1}$

\subsection{Soil Organic Carbon Stock in Different Slope Gradients}

It was found that the highest mean carbon content was computed in lower slope classes i.e. 124.44 \pm 7.69 ton $\mathrm{ha}^{-1}$ and lowest in higher slopes i.e. $81.49 \pm 6.81$ ton ha $^{-1}$ with $95 \%$ CI. The lowest total SOC was measured in slope classes between 31-40.

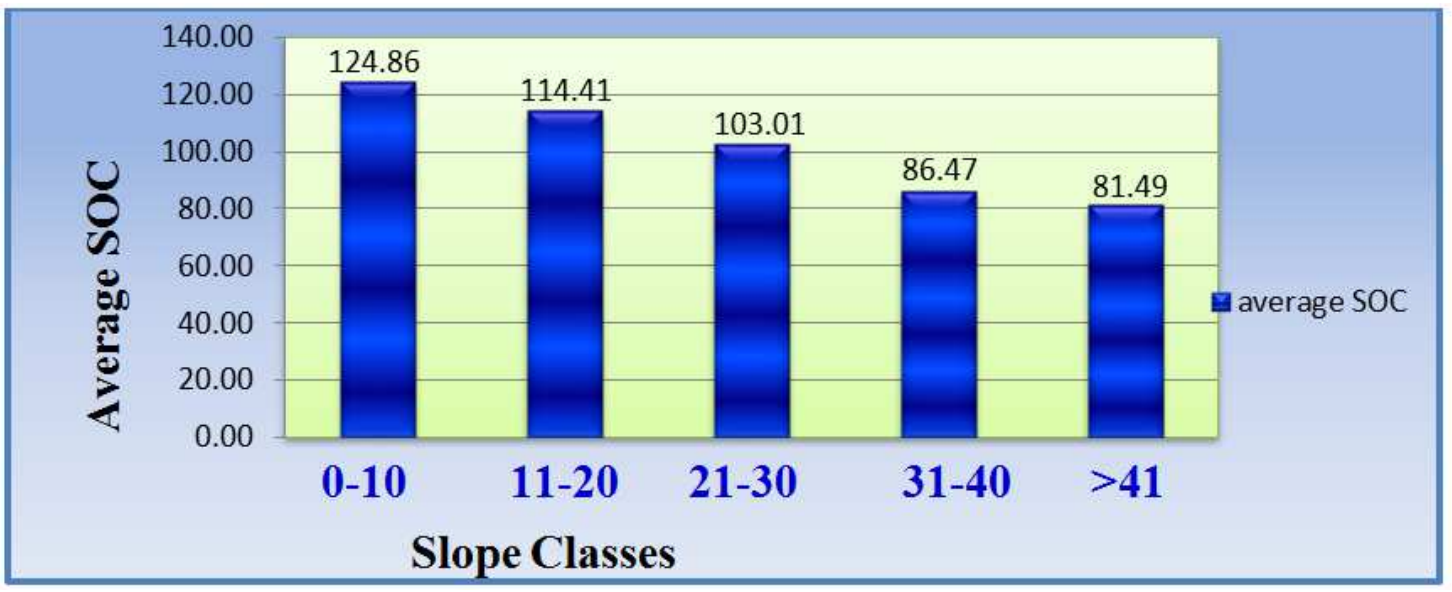

Figure 2. Shows the average soil carbon distribution graph in different slope classes. 
In general, as it is shown in figure 2 above, the overall SOC distribution along different slope gradients decreases with increasing slope. However, there was no statistically significant $(\mathrm{F}=0.858, \mathrm{P}=0.643)$.

Table 2. The total and mean soil carbon stock in varying altitudes.

\begin{tabular}{lllll}
\hline Elevation & Total SOC & Total SCO & Mean SOC & ${\text { Mean } \mathbf{S C O}_{2}}$ \\
\hline Lower & 1692.02 & 6209.70 & $80.57 \pm 3.75$ & $295.70 \pm 13.76$ \\
Middle & 1170.25 & 4294.81 & $90.02 \pm 5.60$ & $330.37 \pm 20.55$ \\
Higher & 3810.82 & 14095.79 & $120.03 \pm 5.01$ & $440.49 \pm 18.40$ \\
\hline
\end{tabular}

In spite of the stock variations in different altitudinal ranges, there was no statistically significant difference between mean values $(\mathrm{F}=0.739, \mathrm{P}=0.788)$. In general, increasing or decreasing altitudinal gradients in the study site has direct relationship with SOC stock distribution pattern. As elevation increases, the SOC stock potential increases and also decreases in decreasing elevation.

\section{Conclusion}

The research was conducted to estimate and quantify the soil carbon stock of the forest in the established $66\left(1 \mathrm{~m}^{2}\right)$ plots. The soil organic carbon content of this forest has been assessed with respect to different environmental variables like slope and altitude gradients. All in all, this study gives estimation of the soil carbon stock in Sekelemariam State Forest. As the results show that there are significant variations in soil stock potential along varying elevation and slope. The middle elevation of the study area is relatively a higher slope gradient and is occupied by sparsely populated natural plants.

\section{References}

[1] Adugna F, T. Soromessa, Mekuria A. 2013. Forest carbon stocks and variations along altitudinal gradients in Egdu forest: implications of managing forests for climate change mitigation. Sc Technol Art Res J. 2013; 2 (4): 40-6.

[2] Axel Don, Jens Schumacher, Annette. 2011. Freibauer Impact of tropical land use change on soil organic carbon stocks - A meta-analysis. Global Change Biology 17 (4): 1658-1670. DOI: $10.1111 /$ j.1365-2486.2010.02336.x.

[3] Bhishma, P. S., Shiva, S. P., Ajay, P., Eak, B. R., Sanjeeb, B., Tibendra, R. B., Shambhu, C., and Rijan, T. 2010. Forest Carbon Stock Measurement: Guidelines for measuring carbon stocks in community-managed forests. Funded by Norwegian.

[4] Brown S. 1997. Estimating Biomass and Biomass Change of Tropical Forests: A Primer. FAO Forestry Paper 134. FAO, Rome.

[5] Drake JE, Gallet-Budynek A, Hofmockel KS et al. 2011. Increases in the flux of carbon belowground stimulate nitrogen uptake and sustain the longterm enhancement of forest productivity under elevated CO2. Ecol Lett 14: 349357.

[6] FAO. 2006b. Global forest resources assessment 2005 Progress towards sustainable forest management. FAO Forestry Paper No. 147. Rome, Italy.

[7] Gregory N. Okolo, Raymond C. Everson, Hein W. J. P. Neomagus, Richard Sakurovs, Mihaela Grigore, and John R. Bunta. (2019). Dataset on the carbon dioxide, methane and nitrogen high-pressure sorption properties of South African $\begin{array}{llll}\text { bituminous } & \text { coals. } 25: & 104248 . & \text { doi: }\end{array}$ 10.1016/j.dib.2019.104248.

[8] Gregory, A., Dungait, J., Watts, C., Bol, R., Dixon, E., White, R., and Whitmore, A. 2016. Long-term management changes topsoil and subsoil organic carbon and nitrogen dynamics in a temperate agricultural system, Eur. J. Soil Sci., 67, 421-430.

[9] IPCC. 2006. IPCC Guidelines for National Greenhouse Gas Inventories Volume 4. Prepared by National Greenhouse Gas Inventories Program, (Eggleston H. S., Buendia L., Miwa K., Ngara T. and Tanabe, K. eds), Institute for Global Environmental Strategies (IGES) Publishing, Hayama, Japan.

[10] IPCC. 2007. Climate change 2007: The physical science basis (Cambridge University Press, Cambridge, UK and New York, USA, 2007).

[11] Jessica L Schedlbauer, Kathleen L Kavanagh. 2008. Soil carbon dynamics in a Chrono sequence of secondary forests in northeastern Costa Rica. Forest Ecology and Management, Elsevier Vol. 255 (3-4) P 365-1366.

[12] Jha MN, Gupta MK, Saxena A, Kumar R. 2003. Soil organic carbon store in different forests of India. Indian Forester 129: 714-721.

[13] Malhi, Y and J. Grace. 2000. Tropical forests and atmospheric carbon dioxide. Tree 15: 332-337.

[14] Pearson, T., Walker, S. and Brown S. 2005. Sourcebook for Land Use, Land-Use Change and Forestry Projects, Winrock International and the Bio-carbon fund of the World Bank.

[15] Rattan Lal, João Carlos De Moraes Sá, Warren A Dick, Solismar de Paiva Venzke Filho. 2001. Organic Matter Dynamics and Carbon Sequestration Rates for a Tillage Chronosequence in a Brazilian Oxisol. Soil Science Society of America Journal 65 (5). DOI: 10.2136/sssaj2001.6551486x.

[16] Sasirin Srisomkiew, Pitayakon Limtong, Supawat Chaikasem. 2017. Correlation between soil organic carbon and land use, slope class and soil texture in chaing rai province of Thailand. GLOBAL SYMPOSIUM ON SOIL ORGANIC CARBON, Rome, Italy, 21-23.

[17] Wibowo A, Wilson JL, Gad EF, and Lam NTK. 2010. Collapse Modelling Analysis of a Precast Soft-Storey Building in Melbourne. Engineering Structural Journal, Elsevier. Special Issue: Learning Structural Failures, Vol. 32 (7), July, pp 1925-1936.

[18] Yitebitu Moges, Zewdu Eshetu and Sisay. 2010. Forest Resources: Current Status and Future Management Options In View Of Access to Carbon Finances. 